\title{
Poesia, Pós-Poesia e Pós-Espanto EM A MORTE DE TONY BENNET, DE LEONARDO GANDOLFI
}

\author{
Alberto Pucheu \\ Universidade Federal do Rio de Janeiro - UFRJ
}

Seria possível dizer que um modo determinante do começo da filosofia surge como uma interpretação do poeta e da poesia. No Íon, de Platão, Sócrates atravessa o diálogo mostrando ao personagem que o intitula que o poeta e o rapsodo não atuam por técnica nem por episteme. Havendo no respectivo texto essa vertente negativa, há, igualmente, uma outra, afirmativa, a dizer quem são o poeta e o rapsodo. É certo, então, que eles não estão em si, que o senso não está mais neles, que eles estão fora de si. Estando fora de si, foi um deus que retirou deles o senso, utilizando-se deles como servidores, fazendo com que estejam possuídos, ou seja, o que, no diálogo, move o poeta e o rapsodo é uma potência divina, uma concessão divina. Por não estarem em si, por estarem em alguma divindade (a Musa, Apolo, Dionísio), os poetas são chamados de seres sagrados, leves, alados. Algo os tira do chão, os faz voar, dando a entender que o que pesa em nós é a própria humanidade, da qual, inumano, o poeta, ao menos temporariamente, se livra ("não são humanos estes belos poemas, nem de homens, mas divinos e de deuses"). Parece que o que pesa é a própria humanidade. Ou seja, movido pelo deus, o poeta e o rapsodo não são aqueles que poetam pela exclusividade da técnica nem da episteme, mas pela força maior do entusiasmo que os toma ao estarem fora de si. $\mathrm{Na}$ medida em que não são os poetas e rapsodos que falam, mas, por eles, os deuses, que, assim, se fazem ouvir por nós, eles são incapazes de poetar sem terem ficado entusiasmados e sem estarem fora de si. Os poetas são porta-vozes dos deuses e os rapsodos são porta-vozes dos porta-vozes dos deuses, sem que haja perda no que, imantando-os, foi enviado. Demarca-se então essa articulação entre o fora de si e o entusiasmo, experiências e termos que não deixarão de, de diferentes maneiras, se tornar preponderantes no dito de poetas e teóricos futuros em suas reflexões e em seus depoimentos sobre a poesia.

Uma pergunta poderia ser feita seria: como se dá a passagem do em si para o fora de si, do poeta e do rapsodo à divindade, de seus sensos para o fato de serem insensatos, do humano para o inumano, de suas individualidades para se tornarem possuídos, portavozes, servidores, intermediários, médiuns, intérpretes, tradutores? Platão também nos responde isso: no caso da poesia lírica, que, cantada, vem com a música, é mais explícito: é pela harmonia e pelo ritmo, ou seja, por algo na concretude da própria musicalidade da lira 
e das palavras que, levados para fora de si, eles se tornam possuídos. Mas e quando, como na épica, ainda que rítmica, a poesia não é cantada? Platão também nos indica, através das palavras de Sócrates: "Mas, espere aí, dize-me isto, Íon, e não me escondas o que quer que eu te pergunte: quando tu bem recitas versos épicos e arrebatas completamente os espectadores, seja quando canta Ulisses tomando de assalto a soleira da porta, revelando-se aos pretendentes e espalhando as flechas diante dos seus pés, ou Aquiles lançando-se sobre Heitor, ou uma daquelas [passagens que] suscitam a piedade acerca de Andrômaca, ou acerca de Hécuba ou acerca de Príamo, nessa hora, estás em ti mesmo ou te tornas fora de ti mesmo e a tua alma acredita estar junto das coisas que tu dizes, estando ela entusiasmada, estando seja em Ítaca, seja em Tróia, ou onde quer que os versos se passem?” [grifo meu]. São os versos, os arranjos das palavras, o que é dito, que retira o poeta de si, levando-o para o próprio ditado da e pela poesia, conduzindo o poeta de uma topologia para uma logotopia, em que ele passa temporariamente a habitar.

Ser levado para fora de si em um mundo sem deuses é uma das tônicas da poesia na modernidade. Em sua famosa carta de 27 de outubro de 1818, para Woodhouse, ao falar sobre o gênio poético, sobre a personalidade poética, Keats afirma que ela é diversa do egoístico, que ela não é própria, que ela não tem eu, que ela é tudo e nada, que ela, enfim, não tem personalidade. Não tendo identidade e adentrando sempre outros corpos, Keats formula um paradoxo: se o poeta não tem um si mesmo, e se ele, Keats, é um poeta, onde estaria a surpresa se ele dissesse que não escreveria mais, ou, ainda, como uma opinião nascida em sua própria natureza poderia ser sua se ele não tem nenhuma natureza? Os desdobramentos são repetidos com toda frequência. Em 15 de maio de 1871, em sua ainda mais famosa carta a Paul Demeny, Rimbaud escreve a frase: "Porque Eu é um outro. Se o cobre acorda clarim, nenhuma culpa lhe cabe. Para mim é evidente: assisto à eclosão de meu pensamento: eu a contemplo, eu a escuto". Além da muito conhecida carta de 13 de janeiro de 1935 para Casais Monteiro, na qual fala de um "Fernando Pessoa ele mesmo", na qual explica sua "despersonalização dramática" e na qual afirma que "em tudo isso me parece que fui eu, criador de tudo, o menos que ali houve. Parece que tudo passou independentemente de mim", em outro conhecido texto do mesmo ano, "A gênese dos heterônimos", Fernando Pessoa afirma: "Hoje, já não tenho personalidade: quanto em mim haja de humano, eu o dividi entre os autores vários de cuja obra tenho sido o executor. Sou hoje o ponto de reunião de uma pequena humanidade só minha". E depois: "Médium, assim, de mim mesmo todavia subsisto. Sou, porém, menos real que os outros, menos coeso [?], menos pessoal, eminentemente influenciável por ele todos". 
Pode-se imaginar a longa tradição que vinda, ao menos desde Platão, ou melhor, vinda ao menos desde Homero, e passando pelos poetas mencionados e outros, será desdobrada nos importantes textos teóricos do século XX, como os de Barthes, Foucault, Agamben e Michel Collot, entre outros. Mas não cabe aqui retraçar essa história nem entrar propriamente na discussão de cada um desses ensaios. O que aqui é possível é tão somente a observação de que, ao menos desde a carta de Keats (e tanto na de Rimbaud quanto na de Pessoa), o vínculo entre o poeta e o fora de si ou o negativo de si está preservado, mas nenhum deus comparece nesses depoimentos pensados. Se, ainda que como uma possibilidade de leitura, a retirada ou a morte dos deuses for assumida, seria possível falar em entusiasmo e modernidade, ou entre entusiasmo e contemporaneidade? Como a palavra entusiasmo traz a divindade em si e como, ao menos os poetas mencionados não mais a mencionam quando falam da ausência de identidade do poeta, talvez haja outra palavra traduzida da tradição do pensamento grego que possa nos ajudar, na nossa tentativa de pensar a permanência dessas questões por um poeta contemporâneo.

A articulação entre poesia e espanto é antiga na história da filosofia e na da poesia. Seguindo Platão, que havia escrito que a origem da filosofia é o espanto, Aristóteles, na Metafísica, faz uma colocação decisiva, que, desde então, não será mais esquecida: “Através do espanto, pois, tanto agora como desde a primeira vez, os homens começaram a filosofar [...]. Mas aquele que se espanta e se encontra sem caminhos reconhece sua ignorância. Por conseguinte, o filômito é, de certo modo, filósofo: pois o mito é composto do admirável, e com ele concorda e nele repousa". Há, pelo menos, três assertivas em tal passagem. A primeira, inteiramente platônica: a de que para haver filosofia tem de haver espanto, pois é através dele que, desde sua origem até sempre que ela houver, a cada vez, inevitavelmente, a filosofia se faz; na segunda, para nossa sorte, uma breve explicação de quando o espanto se dá: o espanto se dá quando, diante da aporia, diante do impasse, diante da ausência de alternativas a serem seguidas, reconhecemos nossa ignorância, mergulhando no não saber que a caracteriza; por fim, é exatamente o compartilhar dessa experiência do impasse e da ignorância que faz com que o filósofo e o poeta, de alguma maneira, sejam o mesmo, já que também no mito, no poético, como no filosófico, há a força constitutiva do espantoso ou do admirável, confundida com a aporia. Não à toa, no verso 485 de Édipo rei, esvaziando a possibilidade de qualquer fala, assinalando a aporia enquanto o não ter mais o que dizer, 
enquanto o não poder dizer, enquanto a impotência de dizer, o coro, na tradução de Trajano Vieira, afirma: “Aporia: dizer o quê?”. A aporia é, portanto, a negação - a ser sempre resguardada - da passagem de todo e qualquer sentido que vier a aparecer, a negação da passagem que mostra que todo sentido é um aparecimento ocorrido por uma passagem derivada do impasse, no qual o sentido é fundado e que, enquanto ignorância, enquanto um não saber, o constitui inapelavelmente. E, para um poeta e para um filósofo gregos, isso parece ser o mais espantoso, sendo, pelo fato de fazerem tal experiência, sem abrir mão dela, preservando-a, que, de certo modo, são o mesmo.

Em certo momento de um dos poemas de Drummond em que o poético e o filosófico se tornam indiscerníveis na reflexão sobre o canto poético, "Nudez", de A vida passada a limpo, surge uma frase que poderia soar, à primeira leitura, bombástica para a história do pensamento da poesia: "E já não sei do espanto." Como assim? Em um de seus poemas mais paradigmáticos e mais densos de poeticidade e pensamento, o poeta não se espanta? Se Drummond afirma que já não sabe do espanto, estaria dizendo que no poema ele está cheio de caminhos disponíveis, cheio de passagens, cheio de facilitações, cheio de saberes, a afastá-lo do que desde o começo do Ocidente era o admirável motor da poesia e do pensamento? Será que, em "Nudez", não há o enfrentamento da aporia, do impasse e a consequente ausência de saber? Fosse assim, Drummond não seria poeta, pelo menos, o poeta que é. Parece-me exatamente o contrário: com a predominância dos decassílabos e a forte dose de trabalho sonoro, imagético e sintático, "Nudez" é um desses poemas em que a aporia se coloca para o poeta em sua dimensão maior, mais radical, exigindo-lhe manifestá-la a cada momento. Seu fundamento poético (e filosófico) está colocado e desenvolvido verso a verso, frase a frase, sem qualquer desvio: "Minha matéria é o nada". Tendo o nada por matéria, o poema, do começo ao fim, dá vazão à manifestação do nada em sua própria materialidade através das negativas adverbiais constantes (não, nunca, jamais, nem), repetidas, por exemplo, no sintagma retornante cujo complemento vai recebendo variações ao longo de "Nudez" ("Não cantarei [... ]"), chegando a "Não cantarei o morto: é o próprio canto”. Enquanto revelação maior do negativo, o que está morto não é assunto do poema, mas o poema ele mesmo se confunde com a dimensão da morte, da pura ausência, sendo-a. O poema é o morto, sua matéria é o nada.

Tanto a conjunção "se" quanto a adversativa "mas" como as interrogações também estão por ali para, colocando o condicional, o opositivo e a dúvida, levar a incerteza a uma ou outra afirmação até esvaziá-la por completo. No mergulho no impasse inultrapassável de o poema se misturar ao nada, à falta, à ausência, o poeta foge de qualquer coisa, enfim, 
capturada, e, como Aristóteles havia proposto, o não saber caracterizador da aporia desde a qual o espanto poético e filosófico se realiza, a negar inclusive o canto, é anunciado: "Não canto, pois não sei". No fim, um pouco depois dos vocativos reforçarem as exclamações e perplexidades, as contraimagens admiráveis, em que o que é dado é simultaneamente retirado, em que a imagem não está para mostrar algo, mas para tirar a possibilidade de qualquer manifestação até esvaziá-la por completo, em que as contraimagens não querem dizer mais, mas, a cada vez, "ainda menos", para dizer o nada da "Nudez" que intitula o poema e com a qual ele se confunde, fazendo-a irromper: "E já não brinco a luz. E dou notícia/ estrita do que dorme,/ sob placa de estanho, sonho informe,/ um lembrar de raízes, ainda menos/ um calar de serenos/ desidratados, sublimes ossuários/ sem ossos; / a morte sem os mortos; a perfeita/ anulação do tempo em tempos vários,/ essa nudez, enfim, além dos corpos, / a modelar campinas no vazio/ da alma, que é apenas alma, e se dissolve." "Nudez" é o poema do espanto e é necessário ser rigoroso: o poeta não afirma que não se espanta, mas que já não sabe do espanto. Se, como visto, o espanto se caracteriza pela ignorância, pelo não saber, o poeta, tão dentro do espanto, sendo-o num grau extremo, já nem sabe dele. Há que se colocar uma ênfase no "E já não sei [d]", para só então, a ênfase tomar a direção de “ [o] espanto" que de fato, no poema, toma o poeta, a ponto de, dele, ele nem saber. Quanto mais aporeticamente ignorante (inclusive do espanto), quanto mais intenso o impasse que o toma, mais no espanto o poeta está. Nesse sentido, o verso diz o contrário do que, a princípio, parece dizer.

Esta breve explicação deve ser suficiente para ser mostrado que o que em Leonardo Gandolfi, um poeta recente na faixa dos 30 anos, poderia parecer a princípio no âmbito da aproximação do passado se coloca sobretudo como seu afastamento. Um afastamento e tanto, um afastamento radical de Drummond, de boa parte do passado da poesia e mesmo do presente predominante da poesia, mas que desenvolve algumas das virtualidades anteriormente presentes na poesia brasileira e mundial, deixando sua marca de distinção precisamente no abismo e na tensão entre corte e preservação, divisão e continuidade. Tensionando o espaço entre aproximação e afastamento, persistência e ruptura, seu trabalho ajuda a criar essa reversibilidade instável em que os duplos se dobram sobre seus pares, tão característica do nosso tempo. Em "Desaparecimento de Agatha Christie", primeiro poema de $A$ morte de Tony Bennett do mesmo modo como, coincidentemente, "Nudez" o é de $A$ vida passada a limpo, uma colocação acerca do nosso tempo e da poesia de nosso tempo está posta: "Nessa hora/ quando tudo parecer sem razão/ ou regresso, quando a procura/ não for mais que descompasso e divisão,/ nada de espanto”. É 
importante frisar que tal trecho surge em um poema que é uma espécie de súmula da espionagem, de como o espião deve agir. Que o processo de espionagem, com seu jogo de duplos, sombras e espelhos, está, no livro $A$ morte de Tony Bennett (2010), implícita e inteiramente associado ao da poesia, será mostrado em breve. Ambos sendo duplos, sombras e espelhos, o espião e o poeta agem de modo afim. Ainda não se sabe que modo é esse, mas se sabe então que, no jogo tanto da espionagem quanto no do fazer poético que, no caso, lhe corresponde, chega-se a uma hora decisiva, em que não se pode regressar a uma ideia exclusiva de poeticidade antiga. "Playtime" adverte: "[...] Cansaço espanto/ dormência, tudo encontra seu fim".

Leonardo Gandolfi dá voz a uma formulação que, do ponto de vista privilegiado na história, seria terrível: a de que o nosso tempo é, entre outras coisas, o do fim do espanto, ou, pelo menos, de que o nosso tempo tem de lidar com o fim do espanto, que também o caracteriza. Com a perda de uma compreensão de poesia que já foi e não tem como exclusivamente voltar, tudo acaba por parecer sem razão, inclusive o fazer poético e os modos de se fazer poemas, requisitando-se então novas maneiras a serem instauradas. Alguma coisa, a começar talvez pela elegância, foi perdida, mas algo novo surge. É claro que a procura pela poesia continua, do mesmo modo que a aporia aristotélica insiste em se valer permanecendo nessa hora em que, sem chance de volta e com a razão perdida, tudo que o processo de busca encontra é "descompasso e divisão". Rompendo, agora, em algum grau, com uma compreensão de poético que vem desde Platão e Aristóteles e atravessa Drummond, o que há de novo, de singularidade e de diferença na poesia de Leonardo Gandolfi é o que vem, no livro, curiosamente, dividido do que lhe precede pelo fim da página e pela necessidade de se virar a página, como um longo enjambement, para lê-lo: "nada de espanto". Uma poesia em confronto com os impasses e descompassos aporéticos, mas sem espanto.

O que seria o contrassenso de uma poesia sem espanto? $\mathrm{O}$ que seria uma poesia num tempo em que o espanto, como um dia tudo, encontra seu fim? Retirar o espanto de cena não é retirar o próprio poético? Findado o espanto, não estaria terminado conjuntamente o poético? Não seria o "nada de espanto" o fim do processo criativo? Mas que força tem o criativo, quando tal termo, com maiúsculas e no feminino - Criativa -, se tornou há muito nome de revista para mulheres, vendida em banca de jornal? O "nada de espanto" não parte, entretanto, de uma prepotência da poesia que teria resolvido, por conta própria, de repente, de sua própria voluntariedade, tirar o espanto de sua fonte. Longe disso. O "nada de espanto" da poesia é uma resposta a "uma época em que [com o espanto 
tendo chegado a seu fim] nada se abate sobre nada", como termina o poema "Espiões em apuros", que intitula a primeira parte do livro. Se o nosso tempo é lido como o do fim do espanto e como uma "época em que nada se abate sobre nada", de que adianta a preservação restritiva do espanto, se ele não consegue mostrar a força de sua exclamação, extinta? A aposta é que uma poesia que ouse se realizar, de algum modo, também sem ele ou ao menos com esse intuito - consiga fazer-se afirmativa de um dos vetores de força maior de seu próprio tempo.

Antes de responder com o que vejo de alternativa para dar sequência a uma poesia com "nada de espanto" no fazer de Leonardo Gandolfi, gostaria de lembrar que, em Drummond, a alta e a má poesia, ou a poesia e a antipoesia, ou o canto e o não canto, ou o elevado e o coloquial, ou o culto e o popular, ou o literário e o vulgar, ou o acerto e o erro, se encontram mesclados, já que vivemos num tempo em que a poesia já não pode se afastar da presença de seu negativo. Preservando em vários momentos essa suspensão instável, a poesia de Leonardo Gandolfi intensifica com força a frequência da voltagem do negativo da poesia através de sua - nova - exigência por "nada de espanto" em "uma época em que nada se abate sobre nada". Sem abrir mão da suspensão instável em que o poético e o não poético não se excluem, ele adentra um universo de processo poético (des)criativo ou (não) criativo ou (não) original, retirando, conjuntamente, ao máximo, a força de criação autoral, que, paradoxalmente, retorna de um novo jeito, já que em poesia a imersão radical no (des)criativo acaba por ser uma criação do mesmo jeito que o aprofundamento radical no não autoral finda por demarcar um novo modo e uma nova assinatura de escrita, ainda que desejosamente fragilizada.

Sobre tal experimentação com o negativo da poesia, poderia ser dito o mesmo que, logo depois de dizer em "Pedro e o logro" que "nunca gostei exatamente de poesia, muito/ menos de Manuel Bandeira", confirma que "[...] trata-se de um caminho/ sem retorno". A força do enjambement acentua que a instabilidade ainda maior gerada pelo aproveitamento do negativo da poesia também é um caminho de experimentação. Leitores esperançosos de encontrar a poesia no exclusivo de sua positividade, de encontrar a poesia em seus píncaros (de encontrar A Poesia), confundindo maldosa e equivocadamente as vozes que falam no poema com a do poeta enquanto sujeito biográfico, vão malevolamente acreditar serem autocríticos versos como "[...] acabaria revelando/ o poeta realmente lamentável que tenho sido" (de "A passagem secreta") e "Não importa,/ talvez não voltemos a encontrar por aqui tiros/ perseguições ou coisas do gênero mas apenas/ uma lembrança, a de que a poesia - inclusive/ maus poemas assim - é feita de uma mesma/ substância escura, 
distante e por isso nossa". Outros leitores, com um sorriso cúmplice e uma piscadela de olhos, buscarão outros caminhos, às vezes dúplices, deslizantes, que podem ser usados ora de um modo, ora de outro.

Que elemento é esse explicitamente (des)criativo ou (não) criativo ou (não) original, que se faz com um "nada de espanto" e, em "uma época em que nada se abate sobre nada", em uma época do fim do espanto, toma a duplicidade, o sombreamento e o especulativo da espionagem por paradigma para uma espionagem poética, para escutar o contemporâneo enquanto um tempo em que, duplicando-se, “[...] as horas/ se descolam por generosidade ou fastio"? Talvez por generosidade - e - fastio, o contemporâneo se dá no exato intervalo do descolamento das horas, nessa lufada de respiração que, no cronológico, acaba por separá-lo de si mesmo, instaurando uma respiração e gerando uma duplicidade. Respondo, sem delongas, que tal elemento é a apropriação, o saque, a pirataria, o plágio, a cópia, a transcrição, a repetição inadvertida, a remixagem, o posicionar-se como um D.J. da poesia... Com muitos nomes possíveis, tal elemento garante a repetição de algo anteriormente existido, que não retorna, entretanto, de modo idêntico. No retorno enquanto poema, uma notícia de jornal se descobre outra coisa, a ponto de nem nos darmos mais conta de tal poema ser tirado de uma notícia de jornal. No retorno enquanto poema, uma cena de um filme perde sua história, perde suas imagens, e, com os diálogos rearranjados espacialmente na página, se transforma em outra coisa, a ponto de nem nos darmos conta de tal poema ser tirado de uma cena de um filme. E assim por diante, na repetição, a continuidade de uma série a outra encontra a ruptura. O poema tem o saber de que cada coisa acontecida implica em sua própria negação. O que se repete não é propriamente o que foi, mas a potência do que foi, o que foi enquanto possível, a cada vez renovado. Nenhuma contraposição é então possível entre cópia e invenção, entre repetição e surpresa. E, na repetição, na transcrição, na cópia, enquanto um gesto pós-espanto, a poesia, sem depender de um sopro natural ou metafísico qualquer, assume uma posição pós-teológica (pós-musaica ou pós-entusiástica), pós-autenticidade-original. Desde a epígrafe bandeiriana ("diga trinta e três"), A morte de Tony Bennett é um livro que chega sem fazer alarde, mas, desde então e ao longo de todo ele, é frequente ao leitor a sensação de conhecer alguma coisa do que nele está escrito, de ter a intuição de já ter escutado antes algo do que nele se mostra, de estar familiarizado com elementos daquele universo de palavras, de ser pego por uma musicalidade que soa cotidiana apesar de, na maior parte das vezes, não ser de localização instantânea nem, talvez, se não for investigar, posterior. 
Apesar disso ou por isso mesmo, também é de se notar imediatamente que o livro resguarda uma estranheza rara na poesia brasileira contemporânea.

Um dos poemas mais importantes do livro, "Um espião janta conosco", tem o título apropriado de um verso do poema "Nosso tempo", de Drummond, sem aspas nem itálico, sem o aviso prévio ou posterior de Leornado Gandolfi de que a frase não é sua, mas do outro poeta, sem, portanto, que a fonte seja revelada. Quem, senão um leitor atento e com ótima memória ou um apaixonado obsessivo ou alguém com ares detetivescos, seria capaz de se lembrar que "O espião janta conosco", título do poema de Leonardo Gandolfi, é parte de um verso de um longo poema de Drummond? Ao mesmo tempo, entre os amadores que durante uns dias leram e em outros dias releram Drummond, quem não guardaria tal verso esquecido em algum lugar longínquo na latência da memória, tão longínquo a ponto de não se lembrar dele, mas não longínquo o suficiente para não deixar de reconhecer algo de familiar naquela frase ao lê-la tempos depois, sem que soubesse exatamente o quê proporcionava aquele tom de proximidade? Tal possibilidade de lembrança completa ainda diminui com a estranheza das palavras reescritas, sem aspas, sem itálico, sem aviso da autoria alheia, saqueadas e remixadas por Leonardo Gandolfi, que lhes dá um contexto inteiramente diverso do de sua origem, sem que nada tenha mais mesmo a ver com o local de sua proveniência. Nessas apropriações deslizantes, nesses saques deslocadores, nessas remixagens móveis a nos causarem uma sensação qualquer de déjà-lu, começa o jogo de duplicidade que a figura do espião e do inspetor de polícia encarna e que atravessa todo o livro.

Como característica da espionagem, é frequente no livro o duplo, a sombra, o espelho; desdobrando-os, também é comum aparecerem mapas, catálogos, mercados negros, uma banda cover dos Beatles, a voz de um mágico ilusionista, um nome de pintor que é também nome de rua, um compositor de fato existente falando ao longo de todo um poema que lhe empresta integralmente a voz, um poema traduzido sem que se diga que é tradução, outro poema que é praticamente uma cópia em versos de uma notícia de jornal sem que isso seja indicado, a apropriação de versos de poetas em que apenas o mínimo é alterado, uma voz em off, um aneurisma cerebral em uma pessoa amada que lhe provoca alterações de comportamento, além de colocações de princípio como "todo nosso esforço resumido/ nessa ideia da sombra [...]”, “A sala com espelho duplicava os objetos/ mesa cadeira e inclusive o sigilo", "[...] Porque no jogo o adversário sempre/ suposto nada mais faz que antecipadamente repetir/ as nossas principais jogadas [...]”, “[...] Talvez/ essa história comece durante o show de uma banda/ cover dos Beatles e a banda cover apesar/ 
da desconfiança natural de qualquer um era boa", "Sintoma do duplo que afetaria toda uma vida [...]", expressões tais quais "Tête-à-tête" e "como dizem", a história real de um escritor que mata verdadeiramente sua mulher e usa o crime como ponto de partida de um livro, o mais famoso cantor e compositor popular brasileiro que diz ter feito uma música importante já imaginando a versão dela em inglês para a voz de um cantor famoso americano etc. etc. etc.

Se, na ambiência do duplo, da sombra, do espelho, o espião e os inspetores de polícia buscam em geral pistas para os crimes, o primeiro criminoso encontrado, o primeiro bandido, o primeiro pirata, é o próprio poeta, espião e bandido a um só tempo. $\mathrm{Na}$ brincadeira de polícia e bandido, ele não se furta a ser os dois. Leonardo Gandolfi é um exímio apropriador da tradição poética dos mais diversos tempos, com a qual lida com enorme liberdade, mas é também um exímio saqueador dos ditados populares e da cultura de massa, como dos jornais, dos best-sellers da literatura policial ou mística, das letras de rock, das letras de canções brega, da pintura pop, dos ready-written ou ready-talked de inspiração duchampiana e dos acontecimentos que giram em torno do que quer que diga respeito à imaginação pública. Passeando pelo livro $A$ morte de Tony Bennett, podem ser encontradas referências diretas ou indiretas a Manuel Bandeira, Dashiel Hammet, Khalil Gibran, Boileau, Leo Huberman, Beatles, Bíblia, Luluzinha, Mônica, Walt Disney, Mickey, Pluto, Tony Bennett, Roberto Carlos, Jaime Gil Biedma, Edgar Allan Poe, Erasmo Carlos, Carlos Drummond de Andrade, Orson Welles, Odair José, Agatha Christie, Joseph Brodsky, Isabel Allende, Guilherme Tell, Françoise Sagan, W.H. Auden, Augusto de Campos, Sebastião Uchôa Leite, Debret, Rugendas, Prokofiev, John Wayne, Jacques Tati, Burt Barcharach, Dione Warwick, Montale, Hegel, Luis Rogelio Nogueras, Lord Byron, Bob Dylan, Rod Steward, Kristian Bala, Zé Ramalho, Gilberto Gil, Big Boy, Sergio Endrigo, Carlos Alexandre, à literatura russa, aos romances baratos, a um livro medieval de bruxaria, e quem mais e o quê mais o leitor for capaz de descobrir. Com uma frequência muito maior do que a que tenho lido por aí, ele imerge com inteligência e singularidade nesse universo de referências mais ou menos conhecido, insistindo nele, sem ser abduzido por ele um só segundo, e sempre obtendo resultados que fisgam consistentemente o interesse do leitor, oferecendo uma renovação da poesia.

Dos 40 títulos do livro, nada menos do que 24 são apropriações exatas ou com ligeiras variações de títulos ou versos de canções (para não falarem que exagero, nem estou computando aqui "O despachante", que a referência a Cabral de "O engenheiro" não é tão explícita e direta, apesar de existir), títulos de poemas de outros poetas, títulos de quadros, 
títulos de filmes, título de história infantil criada em música por compositor erudito, título de conto, título de peça ou ópera e parte de versos alheios. Além da menção ao poema drummondiano "Desaparecimento de Luísa Porto", o primeiro, "Desaparecimento de Agatha Christie", ainda é uma apropriação de um lugar-comum da biografia de uma escritora, mencionado à torto e à direito. 3 são apropriações de expressões de uso comum. 2 (um mais diretamente e outro mais indiretamente) se referem a gêneros de escrita. 1 se apropria ainda de uma passagem de um poema do livro anterior do próprio Leonardo Gandolfi. Ou seja, dos 40, 30 títulos de poemas (75\%) se apropriam de diversos modos do já existente. E estou falando apenas dos títulos.

Um dos títulos não computados na breve estatística acima é "Odpis". Como será mostrado, o poema se refere diretamente ao livro Amoku, do escritor polonês Kristian Bala, cujo título foi alterado por Leonardo Gandolfi para "Odpis”, que é uma palavra polonesa a dizer "cópia", "transcrição". Sendo título de livro, ele poderia estar na contabilidade feita, mas como houve o deslizamento do título original ao qual a história se refere para outro inventado pelo poeta, preferi (não só por isso) lhe dar um lugar de destaque. Por que intitular seu poema com a palavra polonesa para dizer "cópia" ou "transcrição"? O que o poema tem a ver com uma transcrição? O que o poema tem a ver com uma cópia?

\section{ODPIS}

Varsóvia 18 de fevereiro. O escritor polonês Kristan Bala foi condenado a 25 anos de prisão pelo tribunal da cidade de Wroclaw por assassinar o amante da sua mulher e usar o crime como leitmotiv de um livro. O romance Odpis foi publicado em 2004 e logo virou um best seller graças ao rigor e detalhe na descrição do crime cometido pelo protagonista, o que chamou a atenção do cuidadoso serviço de investigação local. Kristian Bala, é claro, disse ser inocente mas o tribunal sem muita dificuldade acabou encontrando inúmeras semelhanças entre o crime do livro e o brutal assassinato em 2000 de W. Z., que mantinha ligações sentimentais e físicas com a mulher do autor. No romance como na vida real, supôs-se, o ciúme levou o protagonista a manter por três dias em cativeiro o amante da mulher. Ao fim comprovou-se, W. Z. teve seu corpo atados pés e mãos jogado no rio Odra. As investigações começaram em 2005 e a grande semelhança entre o crime 
na ficção e a morte de W. Z. foi decisiva para a condenação de Kristian Bala, que passará os próximos 25 anos atrás das grades.

"Odpis" é um desses poemas típicos de Leonardo Gandolfi, desses em que sua dicção mais se confirma. Nele, estão o crime, o serviço de investigação e o livro (um best seller). Nele, estão as múltiplas manifestações do duplo: amante/marido, assassino/escritor, crime/investigação, criminoso/tribunal, romance/vida real, crime/livro com descrição detalhada do crime cometido. Nele, o tom menor de uma narrativa descritiva sem qualquer afetação, conseguindo, com a clareza que o constitui, um efeito poético peculiar, a causar um interesse que nos faz ler o poema com toda a atenção, sem nos desviarmos um instante dele. Nele, uma objetividade que não dá margem para manifestações expressivas de um eu lírico qualquer, ausente, em sua neutralidade, do poema. Nele, está a tensão entre o prosaico e a requisição versificadora que, para mim um de seus mais belos poemas, "Efeito dominó”, faz: "[...] Espero que o corte digamos/ acidental dos versos ajude a criar uma sensação/ de confiança nas palavras, torço também para que/ o tom sugerido ajude a controlar o sentimentalismo/ barato de que tenho ultimamente sido vítima regular". Um poema, enfim, típico de Gandolfi. O mais curioso vem agora. Revelando com autenticidade maior a dicção poética de $A$ morte de Tony Bennett, esse poema é, todo ele, retirado de uma notícia de jornal.

Como pode ser visto no link do blog Direito em Debate - Associação Jurídica do Porto (http://direitoemdebate-ajp.blogspot.com/2007/09/crime-cometido-por-escritordeu-romance.html), no dia 5 de setembro de 2007, uma quarta-feira, foi republicada uma notícia, divulgada originalmente pela LUSA - Agência de Notícias de Portugal, sob o título de "Crime cometido por escritor deu romance e 25 anos de prisão": "Varsóvia, 05 Set (Lusa)- O escritor polaco Kristian Bala foi condenado a 25 anos de prisão por um tribunal da cidade de Wroclaw, oeste da Polónia, por assassinar o amante da sua mulher e utilizar o crime como argumento para escrever um romance, noticiaram hoje os jornais polacos./ $\mathrm{O}$ romance, "Amoku" (Cólera), foi publicado em 2004 e rapidamente alcançou grande popularidade na Polónia, graças às descrições pormenorizadas de tudo quanto se relaciona com o assassínio cometido pelo protagonista, numa trama que agora ficou provado ter por base acontecimentos reais./ Kristian Bala declarou-se sempre inocente, mas a verdade é que o tribunal encontrou claras semelhanças entre o crime narrado no livro e a brutal morte, em 2000, de Dariusz J., que mantinha uma ligação sentimental com a mulher do escritor./ No romance, como também na realidade, os ciúmes levaram o protagonista a 
sequestrar o amante da mulher numa cave, sem alimentos, durante três dias, findos os quais o apunhalou e lançou, de mãos e pés atados, ao rio Odra, onde morreria afogado./ A polícia começou a investigação em 2005 e a total semelhança entre o crime na ficção e a forma como Dariusz J. fora assassinado acabou por ser determinante para acusar Kristian Bala, 36 anos de idade e 25 para passar atrás das grades". Não preciso perder tempo mostrando a apropriação. As alterações são mínimas.

Sabe-se que Manuel Bandeira, citado na epígrafe e no corpo do livro, tem o famoso "Poema tirado de uma notícia de jornal", publicado pela primeira vez em jornal estranhamente devolvido a ele, portanto - em 1925 e, em livro, no Libertinagem, de 1930; no caso de Leonardo Gandolfi, o procedimento é realizado, entretanto, sem que seja anunciado, e eu diria mesmo que, com a alternância do nome do livro que dá título ao poema, ele quer ser dissimulado, para parecer um poema original, da própria lavra de uma suposta autoria, que não existe ou, (des)criativamente, (não) originalmente, (não) criativamente, existe porém de uma outra maneira, a beirar a não autoria, mostrando que o nome de um autor não importa tanto assim. No caso de Bandeira, num momento vanguardista de ruptura com o passado, foi preciso revelar imediatamente no título o procedimento, como se a dizer que o poema pode até se apoderar de uma notícia de jornal, resguardando sua poeticidade ao aumentar o campo de ação e de compreensão da poesia com o choque dessublimador desejado. No caso de Gandolfi, o velar do procedimento mostra um novo momento histórico, em que a ação e a compreensão da poesia já se dão em campo ampliado e em que uma simples notícia de jornal pode passar efetivamente por um poema autoral sem que ninguém saiba de sua origem, sem precisar da enunciação do gesto apropriador. O poema pode então ser uma cópia ou uma transcrição de algo previamente existente e a priori não poético, sem que sua procedência seja notificada nem facilmente observada. A diferença é sutil, mas importa. Se for lembrado que o Manifesto Antropofágico afirmava que "só me interessa o que não é meu", se forem lembradas as apropriações feitas por Oswald de Andrade da carta de Caminha, se for lembrado o poema recém-mencionado de Manuel Bandeira, se for lembrado que Drummond, depois de afirmar, em "Consideração do poema", que os grandes poetas ali mencionados "São todos meus irmãos, não são jornais" e que, em "Nosso tempo", coloca "a falsificação das palavras pingando nos jornais", acaba por, no mesmo livro, A rosa do povo, em "Carta a Stalingrado", com a esperança de uma utopia soviética, lembrando "a doce música mecânica" dos linotipos do livro de estreia, dizer que "A poesia fugiu dos livros, agora está nos jornais", fica claro que, com esses poemas-simulacros, a vertente de afastamento pela 
qual Leonardo Gandolfi lida com o passado está, então, historicamente associada à de aproximação, experimentando-a, acentuando possibilidades, até, na intensidade do procedimento, ir para além dela. Nessa poesia, tudo é como uma ou outra vez já havia sido, mas com um ligeiro - e mais do que importante - deslizamento, com uma ligeira - e mais do que importante - derrapagem.

O respectivo poema de Gandolfi e, para além dele, os procedimentos do livro como um todo são a mostragem de um novo momento poético, em que projeto modernista se mostra cumprido, plenamente incorporado: o próprio e o alheio (o original e a cópia) não encontram mais quaisquer separações, a notícia e o poema podem ser intercambiáveis sem aviso prévio nem desconfiança de tal permutabilidade, o poético e o não-poético não conhecem mais zona de distinção nem chocam mais ninguém, a poesia e sua negação são uma e a mesma. Se na história poética do espanto, o poetar implicava o não-ser enquanto o fundamento negativo desde o qual pelo fazer aparecia a obra que original - não existia antes, no momento com "nada de espanto", no momento pósespanto, fica evidenciado que o negativo não se distingue da linguagem, que com ele se confunde. A suposição aqui não é a de que a linguagem emerge de uma origem que lhe precede, mas a de que a linguagem já está desde sempre colocada, inclusive no que se chama de origem, fazendo com que isso que se chama de origem já se dê pelo meio do caminho da linguagem. Pela apropriação frenquente em tal poética de atos da linguagem, é preciso juntar aqui, indiscernibilizando-os, a imagem recorrente em nossa tradição para a potência da criação e do pensamento da tabuinha em branco, da página em branco, da tela em branco, do silêncio, ao conjunto possível de tudo que já foi escrito, dito, cantado, do mais original a qualquer estereótipo, do mais límpido ao puro ruído, de Camões a mensagens enviadas por celular, criando um curto-circuito entre eles... E, assim fazendo, é preciso juntar também, indiscernibilizando-os, o fazer e o tirar, o fazer e o encontrar, o fazer e o desentranhar, o fazer e o copiar, o fazer e o transcrever... Em duas palavras, grafo tal tipo de escrita e outras como: apoesia contemporânea, deixando soar simultaneamente o artigo necessário na pronúncia e o privativo da leitura visual. Na instabilidade inclassificável de apoesia contemporânea, algo sobrevive e algo nasce, e o que nasce é exatamente um tempo de nascimentos, de desdobramentos, de deslizamentos, de derrapagens.

A morte de Tony Bennett está repleto desses procedimentos copiadores ou transcritivos ou apropriadores integrais ou quase integrais ou parciais. Assimilando Platão de um modo inesperadamente contemporâneo, nesta época sem espanto, o poema é afirmativa e literalmente um simulacro. Mas há também no livro uma tática inesperada, de 
quebrar o procedimento apropriador, transcritivo ou copiador pelo contraprocedimento, ou seja, pelo indicar de que certos poemas são de outros poetas ou vozes de outras pessoas, sendo, no entanto, escrito pelo próprio autor, fazendo com que o que é alheio seja lido como original e o que é original seja lido como alheio. No âmbito dos procedimentos e dos contraprocedimentos, há ainda no livro algo intervalar, assinalando, em algo que poderia ser lido enquanto uma terceira série, como autor de determinada frase alguém que de fato não a escreveu, enganando, com o gesto de deslizamento, o leitor. Para distinguir do procedimento e do contraprocedimento, esse intervalar poderia ser chamado de citação com falsas pistas. Como se vê, o jogo das falsas pistas está por todos os lugares de $A$ morte de Tony Bennett.

Já tendo visto uma parte da lida mais diretamente apropriativa ou copiadora ou transcritiva de Gandolfi, bem como os contraprocedimentos e as citações com falsas pistas, ainda há algo, sobre esses mecanismos, de importante a ser dito. Enquanto que em "Inquietudes na poesia de Drummond”, de Vários escritos, Antonio Candido escreve com muita argúcia e beleza que "este distanciamento em relação ao objeto da criação agrava a dúvida e conduz outra vez o poeta a abordar o ser e o mundo no estado pré-poético de material bruto, que talvez pudesse ter mantido em primeiro plano, conservando o ato criador na categoria de mero registro ou notação", acerca do vetor copiador ou transcritivo da poesia de Leonardo Gandolfi, eu diria que é um poeta que lida com o mundo em um estado pós-poético do material linguístico excessivo disponibilizado pelas redes dos múltiplos discursos da poesia, da ficção, das canções populares, da música erudita, da biografia, da crítica, da teoria, da mídia, da tecnologia e da imaginação pública em geral, em que, para além do registro ou da notação e para muito mais além ainda de uma ideia da positividade exclusiva da poesia, exerce, radicalizando sua negatividade, o ato (des)criador ou (não) criativo ou (não) original da apropriação, do saque, da pirataria, do plágio, da clonagem, da cópia, da transcrição, da repetição inadvertida, da reciclagem, da remixagem, da sobreposição.... O que a imersão no negativo desde onde a palavra poética ganha entrada revela não é nada mais do que o gesto contemporâneo por excelência de a própria linguagem se mostrar como linguagem. Se, desdobrando Antonio Candido, Drummond lida com as commodities ou com as matérias-primas da poesia, Gandolfi trabalha, sobretudo, a partir dos bens linguísticos manufaturados, que se mostram paulatinamente enquanto tais.

Atentando-se para o fato de que, desde os gregos, o espanto se coloca no lugar de origem da poesia e de o nosso tempo trazer o vetor de também poder ser lido como uma época em que, com o "fim do espanto", "nada se abate sobre nada", a pós-poesia de 
Leonardo Gandolfi se confunde rigorosamente com o momento histórico apto a ser interpretado como do pós-espanto. É pós-poesia porque a época é igualmente de pósespanto, já que o espanto sempre foi o fundamento da poesia. Importante frisar ainda que, quando falo em pós-poesia e em pós-espanto na diagonal de afastamento tensivo da poesia de Gandolfi e em sua leitura de nosso tempo, ainda considero que estamos no âmbito aproximativo da poesia e do espanto - não fosse isso, o poético e o espanto que acolhem o pós já não precisariam estar aí e, no esquecimento, teriam caído completamente em desuso. No âmbito do poético, a pós-poesia ainda provém do espanto e, com o pós-espanto que ela enuncia, ainda quer, paradoxalmente, afetar o leitor com o espanto do não espanto. Importante ressaltar que, se é na barra entre “Aproximação. / Afastamento.”, que se dá a (pós-)poesia em questão, o pós utilizado, caracterizado pelo movimento de afastamento, não é um termo cronológico que largaria tudo para trás, mas ele se coloca sincronicamente com o movimento poético aproximativo, dobrando-se sobre ele, mesclando-se com ele, muitas vezes, indiscernibilizando-se com ele. Não se reduzindo ao outro nem destituindo a presença do outro com sua existência, na concomitância da interdependência de que precisam, um se verga sobre o outro, a mostrar, também aí, o lugar da barra a impedir que, no âmbito da poesia, qualquer positividade se cristalize. A pós-poesia e o pós-espanto de Gandolfi não vêm para apagar o poético nem o "pré-poético" que Candido assinalou em Drummond, mas, misturando-se a eles, para ampliar cada uma dessas possibilidades, instabilizando-as, lhes conferindo a única certeza de se estar, em poesia, sempre no meio do caminho, sempre, mesmo sem o espanto, demorando na aporia que caracteriza a poesia. Demorando, sobretudo, na aporia que caracteriza apoesia contemporânea. 